\section{Lignit pernye alapú geopolimerek mechanikai tulajdonságainak szabályozása vibrációs tömörítéssel}

SZABÓ RoLAND - Miskolci Egyetem, Nyersanyagelőkészítési és Környezeti Eljárástechnikai Intézet Érkezett: 2019. 01. 17. - Received: 17. 01. 2019. - https://doi.org/10.14382/epitoanyag-jsbcm.2019.12
SZABÓ Roland

A Miskolci Egyetem Mikoviny Sámuel Földtudományi Doktori lskoláiának doktorjelöltje 2018. februárjától. Elökészitéstechnikai mérnöki MSc diplomáiát 2013-ban szerezte a Miskolci Egyetemen. Jelenlegi kutatási témája a speciális tulajdonságú geopolimerek fejlesztése, különös tekintettel a habszerkezetú geopolimer termékekre, elsôsorban ipari hulladékokat felhasználva.

\begin{abstract}
Kivonat
A geopolimerek tömörítése a betontechnológiában alkalmazott módszerekkel történhet, úgymint döngölés, csömöszölés, vibrációs tömörítés, kompaktálás. Jelen tanulmány a lignitpernye alapú geopolimerek vibrációs úton történô tömörítésével foglalkozik. A pernye fổbb tulajdonságainak (szemcseméret-eloszlás, fajlagos felület, nedvességtartalom, ásványos és kémiai összetétel) meghatározása után a tömörítési paraméterek változtatásának (motor excentricitás (amplitúdó), frekvencia, tömörítési idô) a geopolimer próbatestek mechanikai tulajdonságaira gyakorolt hatását vizsgáltam. A próbatestek egytengelyû nyomószilárdságának és testsúrūségének meghatározása 7 napos vizsgálati korban történt. Az eredmények alapján megállapítható, hogy a tömörítési paraméterek változtatása a próbatestek testsũrūségében nem okozott jelentôs eltérést, az értékek 1,4-1,45g/ $\mathrm{cm}^{3}$ között változtak. A szilárdságvizsgálati eredményeknél azonban kimutatható volt a paraméterek módosításának hatása (az értékek 7,9-12,8 MPa között változtak). A vizsgálatok eredményei alapján tömörség és nyomószilárdság szempontjából optimális tömörítési paraméterek a következő́k voltak: excentricitás $10 \%$, motorfrekvencia $50 \mathrm{~Hz}$, tömörítési idố 1 perc.
\end{abstract}

Kulcsszavak: lignit pernye, geopolimer, vibrációs tömörítés, nyomószilárdság, testsûrũség

\section{Bevezetés}

A geopolimerek olyan új típusú, félig-kristályos, háromdimenziós szerkezettel rendelkező szervetlen polimerek, amelyek szilárd aluminoszilikátok vagy alkáli szilikát tartalmú anyagok lúgos ( $\mathrm{NaOH}, \mathrm{KOH}$, Na-szilikát, K-szilikát) vagy savas (foszforsav) aktiváló oldatban való oldásával és reakciójával állíthatók elő. Alapanyagként természetes vagy mesterséges aluminoszilikát ásványi anyagok, illetve ipari aluminoszilikát melléktermékek/hulladékok (úgymint erőmüi pernye, salak, agyag, vörösiszap, metakaolin, perlit, üveg vagy ezek keverékei) használhatók [1-6]. A geopolimerek tulajdonságait az alapanyag összetétele és reaktivitása, valamint az aktiváló oldat összetétele [6-10] mellett a kezelési hőmérséklet és idő [11-13], továbbá az alkalmazott tömörítési módszer is nagymértékben befolyásolja [13, 14].

A geopolimerek (illetve geopolimer betonok) tömörítése a betontechnológiában alkalmazott módszerekkel valósítható meg, melyek a következők lehetnek: vibrációs tömörítés, csömöszölés, döngölés valamint nagy nyomáson történő tömörítés (kompaktálás) [2, 8, 12-15]. A durva és/vagy finom aggregátumot nem tartalmazó geopolimerek esetén elsősorban vibrációs tömörítés az elterjedt.

Chindraprasirt és mtsai [12] lignit pernye alapú geopolimerek bedolgozhatóságát és szilárdságát vizsgálták különböző koncentrációjú $\mathrm{NaOH}$ (10, 15, $20 \mathrm{M})$ és Na-szilikát oldat eltérő arányú keverékét alkalmazva. A próbatestek tömörítését vibrációs asztalon végezték $10 \mathrm{~s}$-ig. Az eredmények alapján megállapították, hogy a $\mathrm{NaOH}$ mennyiségének és koncentrációjának növelésével csökkent a geopolimer paszta bedolgozhatósága és ezáltal a próbatestek szilárdságértékei is.

Živica és mtsai [14] nagy nyomáson (300 MPa) kompaktált metakaolin alapú geopolimerek és kézi tömörítéssel elóállított referenciatestek tulajdonságait hasonlították össze. Eredményeik alapján arra a megállapításra jutottak, hogy a nagy nyomáson tömörített próbatestekben megnőtt az azonos méretü pórusok mennyisége, és egy sokkal finomabb pórusszerkezet (átlagos pórusméret $59 \mathrm{~nm}$ ) alakult ki bennük, mint a referencia mintákban (átlagos pórusméret $814 \mathrm{~nm}$ ). Továbbá azt is megfigyelték, hogy a tömörítés homogénebb szemcseszerkezetet eredményezett, melyet a szemcsék felületének oldásával és ezáltal nagyobb fokú geopolimerizációs folyamattal magyaráztak.

Cheng és mtsai [15] szénmeddő alapú geopolimerek előállítási körülményeit és tulajdonságait vizsgálták. A kísérleteik során az aktiváló oldat/szilárd anyag arány mellett a $\mathrm{NaOH}$ koncentráció és $\mathrm{NaOH} / \mathrm{Na}$-szilikát arány hatását vizsgálták. A geopolimer paszta tömörítését vibrációs asztalon végezték $60 \mathrm{~s}$-ig a kötőanyagban lévő levegő eltávolítása érdekében.

Jelen tanulmány a pernyealapú geopolimer tömörségének vibrációs úton történő szabályozásával foglalkozik. Az elvégzett vizsgálatok kiterjedtek a vibrációs asztal motorjának excentricitás és frekvenciamódosításával, illetve a tömörítési idő változtatásával a mintatestek nyomószilárdságában és testsűrüségében bekövetkező változások detektálására. Emellett vizsgáltam tömörítés hatására a geopolimer anyagszerkezetében bekövetkező változásokat is.

\section{Anyagok, vizsgálati módszerek}

Kísérletek során lignittüzelésből származó nyers erőműi pernyét használtam, amely főbb jellemzőit az 1 . táblázat tartalmazza. A pernye kémiai összetételének meghatározása röntgenfluoreszcens spektroszkópia elemzéssel (XRF) történt, amelynek eredményét a 2 . táblázat mutatja. 


\section{Származás} Mátrai Erőmú (Visonta, Magyarország)

\begin{tabular}{lc} 
Nedvességtartalom $(\%)$ & 0,27 \\
\hline Halmazsúrúség $\left(\mathbf{g} / \mathbf{c m}^{3}\right)$ & 0,72 \\
\hline Szemcsesúrúség $\left(\mathbf{g} / \mathbf{c m}^{3}\right)$ & 1,93 \\
\hline $\mathbf{x}_{10}(\mu \mathrm{m})$ & 10,8 \\
\hline $\mathbf{x}_{50}(\mu \mathrm{m})$ & 52 \\
\hline $\mathbf{x}_{80}(\mu \mathrm{m})$ & 119,3 \\
\hline
\end{tabular}

Fajlagos felület $\left(\mathrm{cm}^{2} / \mathrm{g}\right)$ 1152

1. táblázat Lignit pernye jellemzöi

Table 1. Properties of lignite fly ash

Komponens Pernye alkotó mennyisége, $\mathrm{m} / \mathrm{m} \%$

\begin{tabular}{lc}
$\mathrm{SiO}_{2}$ & 48,1 \\
\hline $\mathrm{Al}_{2} \mathbf{O}_{3}$ & 14,42 \\
\hline $\mathrm{Fe}_{2} \mathbf{O}_{3}$ & 10,97 \\
\hline $\mathrm{Na}_{2} \mathbf{O}$ & 0,37 \\
\hline $\mathrm{K}_{2} \mathbf{O}$ & 1,66 \\
\hline $\mathbf{C a O}$ & 11,76 \\
\hline MgO & 3,34 \\
\hline $\mathrm{TiO}_{2}$ & 0,492 \\
\hline $\mathbf{P}_{2} \mathbf{O}_{5}$ & 0,264 \\
\hline MnO & 0,171 \\
\hline SO & 0,575 \\
\hline LOI* & 2,2 \\
\hline egyéb & 5,678
\end{tabular}

${ }^{*}$ Izzitási veszteség $950{ }^{\circ} \mathrm{C}$-on (Loss on ignition at $950{ }^{\circ} \mathrm{C}$ )

2. táblázat Lignitpernye kémiai összetétele (XRF vizsgálat alapján)

Table 2. Chemical composition of lignite fly ash (XRF measurement)

Az elemzés alapján megállapítható, hogy a pernyében lévő $\mathrm{SiO}_{2} / \mathrm{Al}_{2} \mathrm{O}_{3}$ aránya 3,34, valamint a $\mathrm{SiO}_{2}, \mathrm{Al}_{2} \mathrm{O}_{3}$ és $\mathrm{Fe}_{2} \mathrm{O}_{3}$ tartalom a pernye mintegy $73,49 \mathrm{~m} / \mathrm{m} \%$-át adja. Emellett a mintaanyag relatíve magas $\mathrm{CaO}$ tartalommal $(11,76 \%)$ is rendelkezett.

A mintaanyag ásványos összetételének meghatározása röntgendiffrakciós szerkezetvizsgálati módszerrel (XRD) történt. A pernye fó ásványos összetevői a következők voltak: kvarc (20,34\%), maghemit $(4,22)$, hematit $(3,91 \%)$, anhidrit (7,08\%), albit (4,71\%), albit $\mathrm{K} 0.16(5,58 \%), \mathrm{CaO}(1,61 \%)$ és amorf rész (52,5\%).

\begin{tabular}{|c|c|}
\hline Asztal hasznos felülete & $700 \times 900 \mathrm{~mm}\left(0,63 \mathrm{~m}^{2}\right)$ \\
\hline Motor típusa & Italvibras MVSI 10/310-890-I \\
\hline Motor teljesítménye (50 Hz) & $0,35 \mathrm{~kW}$ \\
\hline Motor fordulatszáma (50 Hz-en) & $\begin{array}{c}1000 \text { 1/perc (frekvenciaváltóval } \\
\text { szabályozható) }\end{array}$ \\
\hline Excenter súlyok & a bezárt szög állítható (0-180) \\
\hline Centrifugális erő (50 Hz) & $3,14 \mathrm{kN}$ \\
\hline $\begin{array}{r}\text { 3. táblázat Vibrációs asztal müszaki jellemzöi } \\
\text { Table 3. Technical characteristics of vibratir }\end{array}$ & table \\
\hline
\end{tabular}

A geopolimerek előállításához használt aktiváló szer 8 $\mathrm{M}$-os $\mathrm{NaOH}$ és vízüveg $\left(\mathrm{Na}_{2} \mathrm{SiO}_{3}\right)$ oldatok keverékéből állt. A $\mathrm{NaOH}$ oldatot 99,99\% tisztaságú szilárd $\mathrm{NaOH}$ granulátumok desztillált vízben való oldásával készítettem, míg a vízüveg 2,7\% $\mathrm{K}_{2} \mathrm{O}$-ot, 13,7\% $\mathrm{Na}_{2} \mathrm{O}$-ot, 25,3\% $\mathrm{SiO}_{2}$-ot és 58,3\% $\mathrm{H}_{2} \mathrm{O}$-ot tartalmazott.

A geopolimer próbatestek tömörítésére szolgáló vibrációs asztal főbb müszaki jellemzői a 3. táblázatban találhatóak.

\section{Kísérletek}

A tömörítési vizsgálatok során először a geopolimer pasztát állítottam elö, amely a lignit pernye és az aktiváló oldat 2 percig történő keverésével történt. Az aktiváló szer/pernye aránya (L/S arány) 0,82 volt. A geopolimer paszta összetételének és hőkezelési körülményeinek (hőmérséklet, kezelési idő) megválasztása korábbi kísérletek eredményei [9] alapján történt. A kapott pasztát előre kiolajozott, 35 mm átmérőjű és 65 mm magasságú műanyag hengeres formákba töltöttem, majd vibrációs asztalon különböző paraméter beállítások mellett (motor excentricitás, frekvencia) egy percig tömörítettem. Tömörítés után a próbatestek hőkezelése történt, amelyet két lépcsőben hajtottam végre. Először a geopolimereket 24 órán keresztül levegőtől elzárva, kondicionáló kamrában $23{ }^{\circ} \mathrm{C}$ on tároltam, majd elektromos kemencében 6 órán keresztül $30{ }^{\circ} \mathrm{C}$-on hőkezeltem. Hőkezelést követően a próbatestek tárolása a nyomószilárdság-vizsgálat elvégzéséig kondicionáló kamrában történt $23{ }^{\circ} \mathrm{C}$-on és $90 \%$-os páratartalom beállítása mellett. A szilárdságvizsgálatra 7 napos korban került sor. Minden esetben $5 \mathrm{db}$ próbatestet vizsgáltam, és a kapott eredmények átlagértékét diagramon ábrázoltam. A vibrációs asztal üzemi paraméterváltoztatása mellett a tömörítési idő hatását is vizsgáltam. A kísérlet során 0,$5 ; 1 ; 2 ; 3 ; 5$ és 10 perces tömörítést alkalmaztam. A próbatestek nyomószilárdsága mellett meghatároztam azok testsürüségét, valamint Fourier-transzformációs infravörös spektroszkópia (FT-IR) elemzéssel a szerkezetükben - tömörítés hatására- bekövetkező változásokat.

\section{Eredmények}

\subsection{Motor excentricitás (amplitúdó-kitérés) változtatásának hatása}

A motor excentricitásának változtatásával a vibrációs asztallap $\mathrm{x}$ és $\mathrm{y}$ irányú kitérésének mértékét (amplitúdóját) tudjuk módosítani. Az 1. ábra jól szemlélteti, hogy a vibromotoron található excentersúlyok pozíciójának módosításával hogyan változott az asztallap helyzete vibráció során. Az excentricitás mértékének növelésével az asztallap horizontális (x irányú) és vertikális (y irányú) kitérése 20\%-os excentricitás értékig növekedett, majd ezt követően az y irányú kitérésben kismértékü csökkenés mutatkozott. Ezzel szemben az asztallap x irányú kitérése az excentricitás mértékének változtatásával növekedett. Ez a változás az

$$
\ln (\mathrm{Y})=0,054 * \mathrm{X}-1,017
$$

exponenciális függvénnyel jól jellemezhető, ahol a determinációs együttható értéke $\mathrm{R}^{2}=0,982$. 


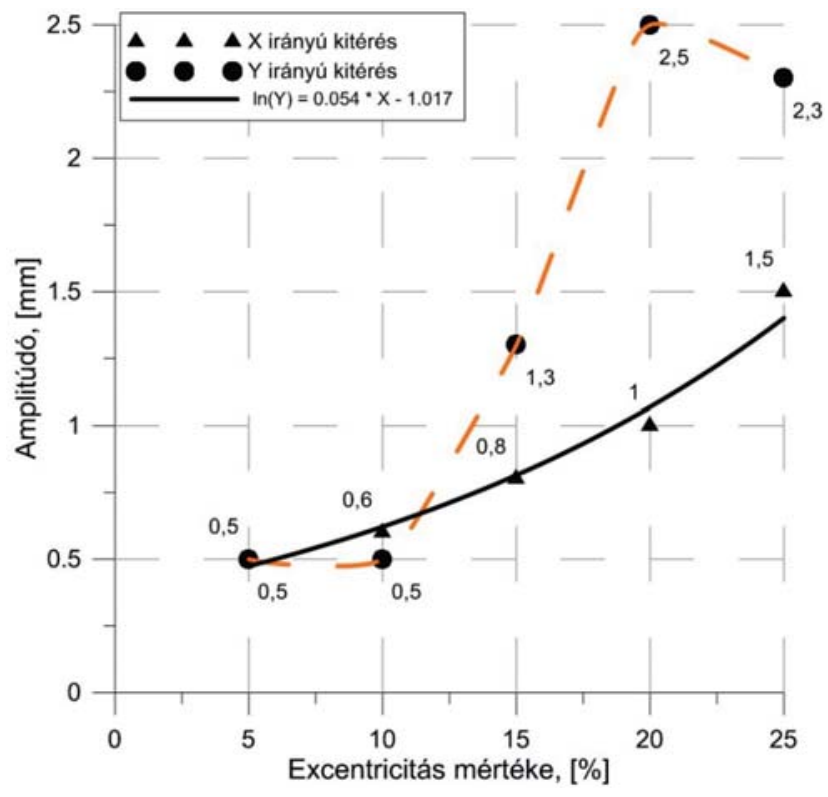

1. ábra Vibrációs asztal amplitúdójának változása az excentricitás függvényében

Fig. 1. Variation of amplitude of the vibrating table as function of the eccentricity

A 2. ábra a próbatestek egytengelyü nyomószilárdság és testsűrüség értékeit ábrázolja a motor excentricitás változásának függvényében. Az ábra alapján elmondható, hogy a vibrációs asztallap amplitúdó változásának mértéke hatással volt a geopolimerek nyomószilárdságára, míg a testsürüségükben nem történt jelentős változás, azok átlagosan 1,42-1,43 g/ $\mathrm{cm}^{3}$ közötti értéket vettek fel. Az excentricitás mértékének növelésével a geopolimerek nyomószilárdságában növekedés tapasztalható egy bizonyos értékig, majd csökkenés figyelhető meg. A legnagyobb szilárdságú geopolimer (12,8 MPa) 20\% excentricitás beállításnál készült.

Fontos megjegyezni, hogy az irodalom alapján a pernye alapú geopolimerek szilárdsága a nyersanyag őrléssel megvalósított mechanikai aktiválásával fokozható [16-18].

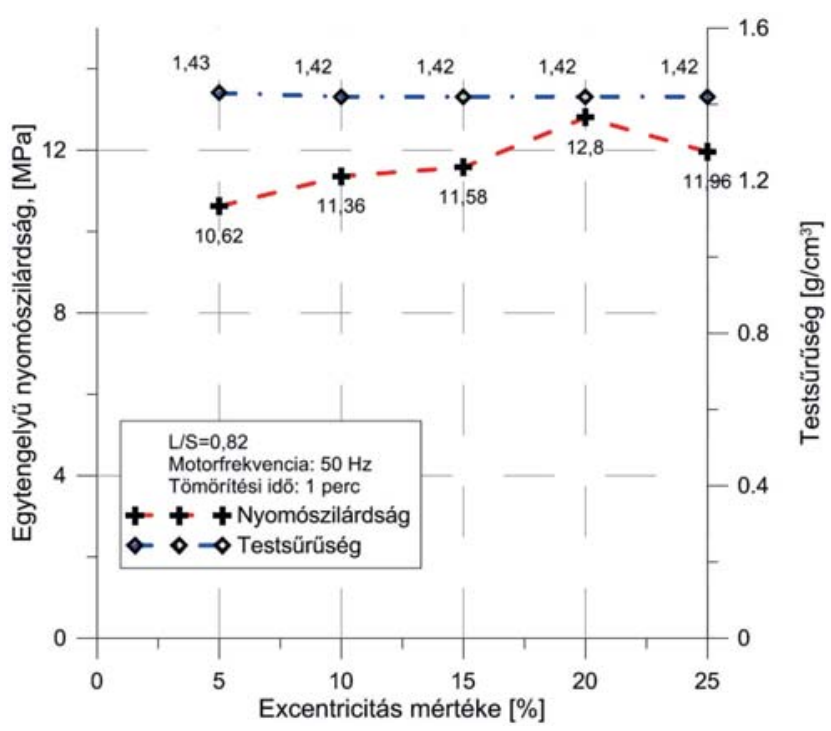

2. ábra Geopolimer nyomószilárdságának és testsűrüségének változása az excentricitás függvényében

Fig. 2. Compressive strength and specimen density of geopolymer as function of the eccentricity
A további vizsgálatot $10 \%$-os beállítás mellett végeztem, mivel magasabb excentricitásnál (20 és 25\%) az asztallap y irányú kitérésében bekövetkező ugrásszerü növekedés (1. ábra) a vibrációs asztal rögzítését hosszabb üzemeltetés esetén károsította volna. Továbbá a nyomószilárdság értékek relatív szórása (4. táblázat) is ennél a beállításnál volt a legkisebb (9,4\%), míg a szilárdság értékek közötti legnagyobb eltérés 15\%-os beállításnál mutatkozott (23,1\%).

\begin{tabular}{ccc} 
Motorexc. [\%] & $\begin{array}{c}\text { Nyomószil. relatív } \\
\text { szórása [\%] }\end{array}$ & $\begin{array}{c}\text { Testsürúség relatív } \\
\text { szórása [\%] }\end{array}$ \\
\hline 5 & 13,7 & 0,8 \\
\hline 10 & 9,4 & 0,4 \\
\hline 15 & 23,1 & 0,3 \\
\hline 20 & 11,9 & 0,4 \\
\hline 25 & 16,5 & 0,60
\end{tabular}

4. táblázat Geopolimer nyomószilárdságának és testsürüségének relatív szórása az excentricitás változtatásával

Table 4. Coefficient of variation of compressive strength and density of geopolymer as function of the eccentricity

\subsection{Motorfrekvencia változás hatása}

Adott excentricitás (10\%) és különböző motorfrekvencia beállítás mellett tömörített geopolimerek nyomószilárdságában és testsürüségében bekövetkező változásokat a 3. ábra szemlélteti. Az ábra alapján megfigyelhető, hogy a rezgésszám (frekvencia) növelésével a geopolimerek átlagos nyomószilárdsága is növekedett. Ugyanakkor az is megállapítható, hogy a vibrációs asztal túl alacsony $(<40 \mathrm{~Hz})$ és túl magas $(60 \mathrm{~Hz})$ rezgésszámon való üzemeltetése a geopolimerek mechanikai stabilitására már kedvezőtlenül hatott. Ezekben az esetben a geopolimerek 10,07$10,71 \mathrm{MPa}$ közötti nyomószilárdsággal rendelkeztek. Ezzel szemben 45-55 Hz között készült próbatestek szilárdságértékei 11,31-11,53 MPa tartományban mozogtak.

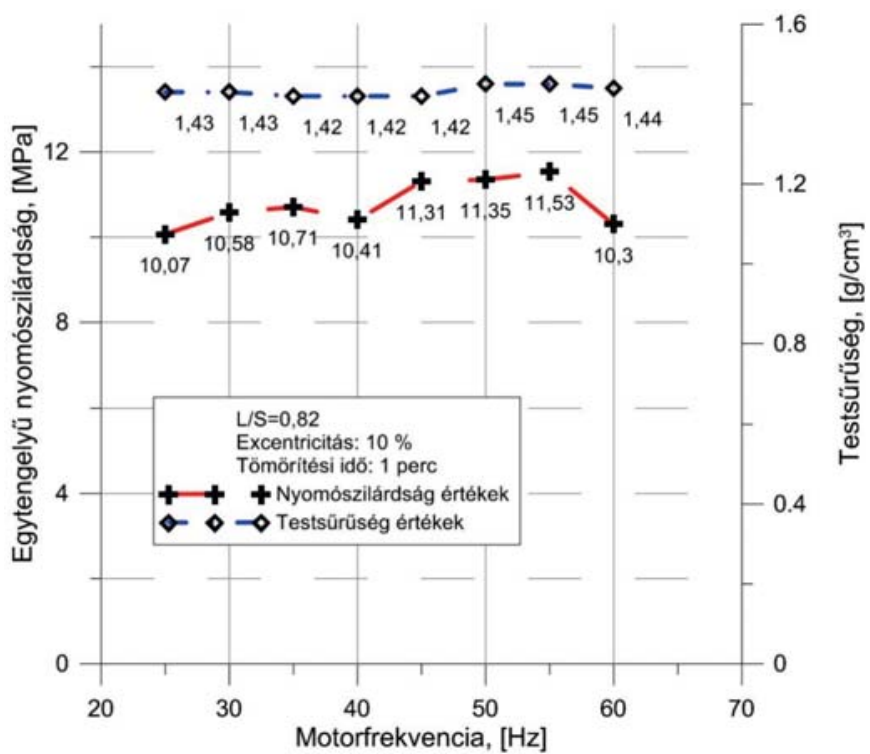

3. ábra Geopolimer nyomószilárdságának és testsűrüségének változása a frekvencia függvényében

Fig. 3. Compressive strength and specimen density of geopolymer as function of the motor frequency 
A geopolimerek testsürüségében nem történt jelentős változás, azok 1,42-1,45 $\mathrm{g} / \mathrm{cm}^{3}$ között változtak. Legnagyobb testsürüsége $\left(1,45 \mathrm{~g} / \mathrm{cm}^{3}\right) 50$ és $55 \mathrm{~Hz}$-en készült próbatesteknek volt. (Ezekben az esetekben mértük a legnagyobb nyomószilárdságokat is.)

$\mathrm{Az}$ eredmények alapján megállítható, hogy a legmagasabb nyomószilárdsággal rendelkező geopolimerek a vibrációs asztal 45-55 Hz frekvencia tartományban való üzemeltetésével állíthatók elö. Továbbá a próbatestek nyomószilárdságának relatív szórása ezekben a tartományokban nem haladta meg a $13 \%$-ot (5. táblázat).

\begin{tabular}{ccc}
$\begin{array}{c}\text { Motorfrekvencia } \\
{[\mathrm{Hz}]}\end{array}$ & $\begin{array}{c}\text { Nyomószil. relatív } \\
\text { szórása [\%] }\end{array}$ & $\begin{array}{c}\text { Testsúrúség relatív } \\
\text { szórása [\%] }\end{array}$ \\
\hline 25 & 5,8 & 0,7 \\
\hline 30 & 9,6 & 0,7 \\
\hline 35 & 14,9 & 0,5 \\
\hline 40 & 12,8 & 0,4 \\
\hline 45 & 10,9 & 0,3 \\
\hline 50 & 12,8 & 0,6 \\
\hline 55 & 10,6 & 0,5 \\
\hline 60 & 12,4 & 0,7
\end{tabular}

5. táblázat Geopolimer nyomószilárdságának és testsűrüségének relatív szórásának alakulása a motor frekvencia változtatásával

Table 5. Coefficient of variation of compressive strength and density of geopolymer as function of the motor frequency

\subsection{Tömörítési idő}

Mivel 50 és $55 \mathrm{~Hz}$-en közel azonos tulajdonságú geopolimerek készíthetőek, ezért a tömörítési idő változtatásának hatását 50 $\mathrm{Hz}$ (hálózati) frekvencia (és $10 \%$ excentricitás) beállításon vizsgáltam.

A vizsgálat eredményeit a 4 . ábra szemlélteti, míg a nyomószilárdság és testsűrüség értékek relatív szórását a 6 . táblázatban foglaltam össze. Az ábra alapján megfigyelhetö, hogy a geopolimerek nyomószilárdsága egy adott tömörítési ideig ( 1 perc) növekedett, majd ezt követően 5 perces tömörítésig csökkenő tendenciát mutatott. Ezután ismét szilárdságnövekedés tapasztalható. Ez a fluktuáció vélhetően a hosszabb ideig tartó tömörítés hatására a keverékben bekövetkező aktiváló oldat- szilárd anyag bizonyos mértékü szétválásával magyarázható, ami rendezetlen geopolimer szerkezet kialakulásához vezethetett. A legnagyobb szilárdságot 1 perc tömörítési időnél mértem (11,73 $\mathrm{MPa})$, míg legkisebb szilárdsággal az 5 percig tömörített próbatestek rendelkeztek $(7,92 \mathrm{MPa})$. A geopolimerek testsürüsége a tömörítési idő növelésével, 2 perces tömörítésnél érte el a maximumot (1,45g/ $\mathrm{cm}^{3}$ ), ezt követően az értékük nem változott. A nem tömörített geopolimerek testsürüsége átlagosan $1,42 \mathrm{~g} / \mathrm{cm}^{3}$ volt.

A geopolimerek nyomószilárdság értékeinek relatív szórását megvizsgálva (6. táblázat), megállapítható, hogy az átlagtól való legnagyobb eltéréssel a tömörítetlen és az 5 percig tömörített geopolimerek rendelkeztek, mindkét esetben az eltérés $20 \%$ fölötti volt (21,1 illetve 29,6\%). A többi esetben az eltérés 15\% alatt maradt (6,7-14,2\%).

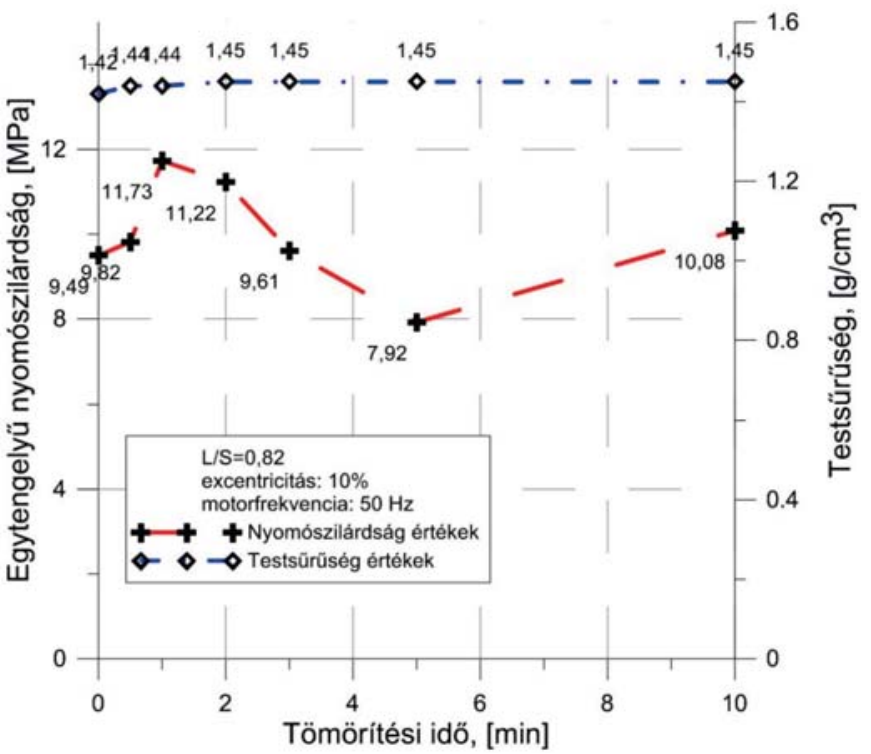

4. ábra Tömöritési idő hatása a geopolimer nyomószilárdságára és testsürüségére Figure 4. Effect of compression time on the compressive strength and specimen density of geopolymer

\begin{tabular}{ccc} 
Tömörítési idő [min] & $\begin{array}{c}\text { Nyomószil. relatív } \\
\text { szórása [\%] }\end{array}$ & $\begin{array}{c}\text { Testsúrüség relatív } \\
\text { szórása [\%] }\end{array}$ \\
\hline 0 & 21,1 & 0,3 \\
\hline 0,5 & 12,6 & 0,8 \\
\hline 1 & 14,2 & 0,3 \\
\hline 2 & 9,8 & 0,6 \\
\hline 3 & 14,2 & 0,3 \\
\hline 5 & 29,6 & 0,4 \\
\hline 10 & 6,7 & 0,6
\end{tabular}

6. táblázat Geopolimer nyomószilárdságának és testsürüségének relatív szórása változása a tömöritési idö függvényében

Table 6. Coefficient of variation of compressive strength and density as function of the compression time

\subsection{FT-IR eredmények}

\subsubsection{Excentricitás}

$\mathrm{Az}$ 5. ábra különböző excentricitáson tömörített geopolimerek FT-IR spektrumát mutatja. Az ábrán látható, hogy az egyes spektrumok közel azonos lefutásúak. Eltérés leginkább az $1415 \mathrm{~cm}^{-1}$-nél jelentkező sávokban (csúcsokban) mutatkozik, amely karbonát jelenlétére (O-C-O kötések nyújtó rezgéseire) utal [19]. E sávok intenzitása 10 és $20 \%$ excentricitáshoz tartozó geopolimereknél volt a legkisebb, amely magyarázatul szolgálhat a magasabb nyomószilárdság értékekre (10\% exc.-nál 11,4 MPa, míg 20\% exc.-nál 12,8 $\mathrm{MPa}$ ). A geopolimerek 15\% excentricitásnál is még átlagosan 11,5 MPa nyomószilárdsággal rendelkeztek, viszont az értékek ebben az esetben igen nagy relatív szórást mutattak (23\%), ami az egyes próbatestekben fellépő karbonát képződés okozta szilárdságcsökkenés miatt következhetett be. 


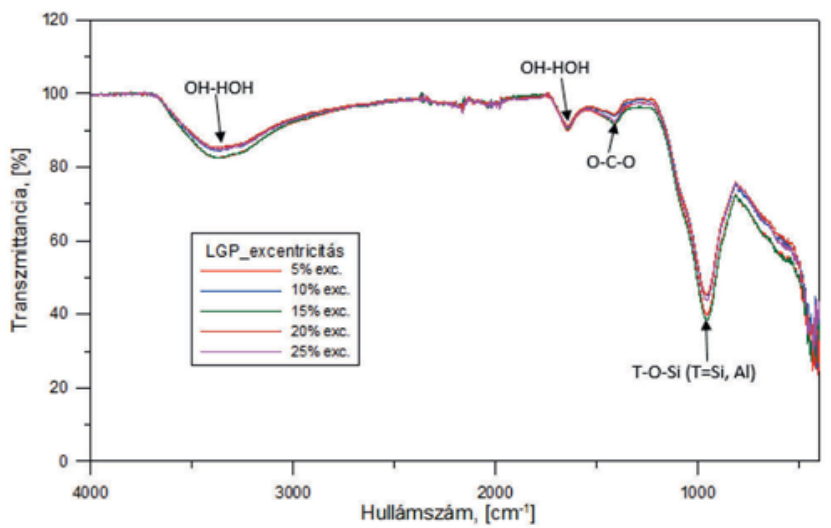

5. ábra Különbözö excentricitáson tömörített geopolimerek FT-IR spektrumai Fig. 5. FT-IR spectras of geopolymers (compression on various eccentricity)

\subsubsection{Frekvencia}

Ha a különböző frekvencián tömörített geopolimerek FTIR spektrumait megvizsgáljuk (6. ábra), megállapítható, hogy azokban nincs számottevő eltérés, a sávok szélessége és intenzitása is közel azonos volt. Mind a $3360 \mathrm{~cm}^{-1}$-nél és 1645 $\mathrm{cm}^{-1}$-nél jelentkező OH-HOH kötésekhez (víz), mind az 1416 $\mathrm{cm}^{-1}$-nél jelentkező O-C-O kötésekhez (karbonát) valamint a $955 \mathrm{~cm}^{-1}$-nél lévő T-O-Si ( $\left.\mathrm{T}=\mathrm{Si}, \mathrm{Al}\right)$ kötésekhez tartozó sávok (csúcsok) intenzitása és szélessége azonosnak tekinthető.

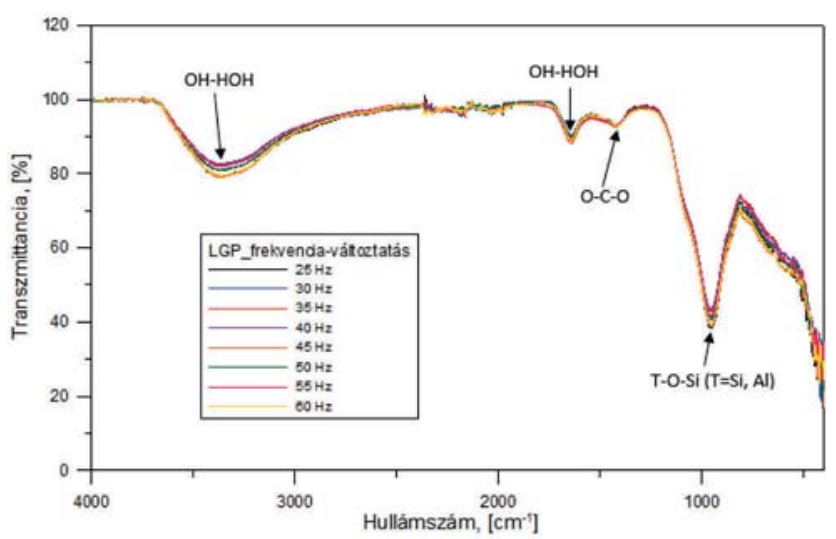

6. ábra Különböző frekvencián tömöritett geopolimerek FT-IR spektrumai Fig. 6. FT-IR spectras of geopolymers (compression on various frequency)

\subsubsection{Tömörítési idő}

A 7. ábra a különböző ideig tömörített geopolimerek FTIR spektrumát mutatja. Az ábrán látható, hogy az egyes geopolimerek spektrumaiban itt sincs számottevő eltérés. Ez alól kivételt képez az 5 percig tömörített geopolimer spektruma, amely kissé elkülönül a többitöl. Eltérés leginkább az 1401 $\mathrm{cm}^{-1}$-nél jelentkező csúcsnál mutatkozik, ami kissé nagyobb intenzitású, mint a többi próbatest esetén. Fontos megjegyezni, hogy a geopolimer 5 perces tömörítésnél rendelkezett a legkisebb nyomószilárdsággal $(7,9 \mathrm{MPa})$, ami vélhetően a jelentősebb karbonátképződés miatt következett be. További eltérés a $950 \mathrm{~cm}^{-1}$ környékén jelentkező csúcsok intenzitásában mutatkozott, ami a T-O-Si $(\mathrm{T}=\mathrm{Si}, \mathrm{Al})$ kötések aszimmetrikus nyújtó rezgéseire utal. Geopolimerizáció szempontjából ennek a csúcsnak a változása (csúcsmagasság és szélesség) jellemző a geopolimerizáció fokára [20].

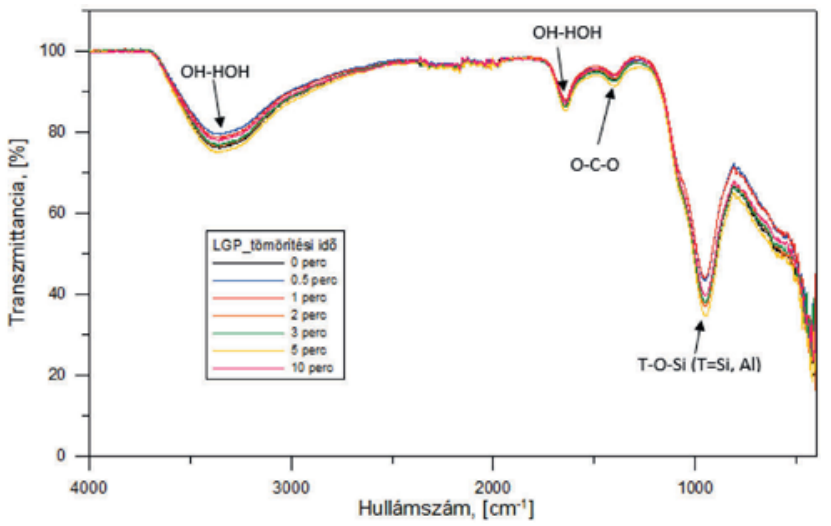

7. ábra Különböző ideig tömörített geopolimerek FT-IR spektrumai

Fig. 7. FT-IR spectras of geopolymers (compression on various compression time)

\section{Megállapítások}

A kutatómunka során geopolimerek vibrációs úton történő szabályozásával foglalkoztam. Vizsgáltam különböző tömörítési paramétereknek (excentricitás, frekvencia, tömörítési idő) a geopolimerek mechanikai tulajdonságaira gyakorolt hatását.

A kísérletek eredményei alapján megállapítható, hogy ezen paraméterek változtatása jelentős hatással volt a geopolimerek nyomószilárdságára, míg a testsürüségben nem volt lényeges változás. Az excentricitás növelése a vibrációs asztallap nagyobb mértékü x és y irányú kitérését (amplitúdó változását) eredményezte, amely változás a geopolimerek nyomószilárdságában is növekedést mutatott.

A motorfrekvencia változtatása során megállapítottam, hogy a rezgésszám növelése a geopolimerek mechanikai stabilitását javította, ugyanakkor túl magas $(60 \mathrm{~Hz})$ frekvenciaértéknél szilárdságromlás következett be. Optimális tartomány 45-55 Hz között volt.

A tömörítési idő is jelentős hatást gyakorolt a geopolimerek tulajdonságaira. A túl rövid (<1 perc) és túl hosszú ( $>2$ perc) ideig tartó tömörítés relatíve alacsony szilárdságú $(<10 \mathrm{MPa})$ geopolimert eredményezett, viszont az optimális tömörítési idő (1 perc) megválasztásával 11,7 MPa szilárdságú geopolimert állítottam elő.

Az FTIR mérések eredményei alapján megállapítható, hogy a tömörítési paraméterek változtatása a geopolimerek szerkezetében nem okozott jelentős átalakulást. Geopolimerizáció szempontjából fontos sávok (csúcsok) mind intenzitásukban mind szélességükben azonosak (vagy közel azonosak) voltak. Új sávok nem jelentek meg egyik esetben sem.

$\mathrm{Az}$ eredmények alapján tömörség és nyomószilárdság szempontjából optimális tömörítési paraméterek a következők voltak: excentricitás $10 \%$, motorfrekvencia $50 \mathrm{~Hz}$, tömörítési idő 1 perc. Ezen paraméter-beállítások mellett átlagosan 11,73 MPa nyomószilárdságú geopolimer állítható elő, amely érték a tömörítetlen geopolimerek szilárdságához képest $(9,49$ MPa) 23,6\%-os szilárdságnövekedést jelent. A geopolimerek testsürüsége a fentebb említett beállításokkal átlagosan 1,44 $\mathrm{g} / \mathrm{cm}^{3}$, ami kismértékű növekedést mutat a tömörítetlen geopolimerek sürüségéhez képest $\left(1,42 \mathrm{~g} / \mathrm{cm}^{3}\right)$. 


\section{Köszönetnyilvánítás}

A tanulmányban ismertetett kutatómunka az EFOP-3.6.1-162016-00011 jelü „Fiatalodó és Megújuló Egyetem - Innovatív Tudásváros - a Miskolci Egyetem intelligens szakosodást szolgáló intézményi fejlesztése" projekt részeként - a Széchenyi 2020 keretében - az Európai Unió támogatásával, az Európai Szociális Alap társfinanszírozásával valósult meg. A szerző köszönetét fejezi ki Móricz Ferenc tanársegédnek és Dr. Kristály Ferenc tudományos fömunkatársnak a pernyeminta kémiai és ásványos összetételének meghatározásáért, Dr. Debreczeni Ákos egyetemi docensnek az egytengelyü nyomószilárdságvizsgálatok elvégzésében nyújtott segítségéért, továbbá Dr. Mucsi Gábor és Dr. Nagy Sándor egyetemi docensnek a témában való iránymutatásukért.

\section{Irodalomjegyzék}

[1] Davidovits, J. (2011): Geopolymer chemistry and application. Institut Geopolimére, ISBN: 9782951482050 pp. 283, 286.

[2] Mucsi G. - Lakatos J. - Molnár Z. - Szabó R. (2014): Development of geopolymer using industrial waste materials. ENVIRONMENTAL ENGINEERING, eISSN 2029-7092 / eISBN 978-609-457-640-9

[3] Komintsas, K. - Zaharaki, D. (2007): Geopolymerisation: A review and prospects for the mineral industry. Mineral Engineering 20, pp. 1261-1277. https://doi.org/10.1016/j.mineng.2007.07.011

[4] Bai, C. - Colombo, P. (2018): Processing, properties and applications of highly porous geopolymers: A review. Ceramics International 44:(14), pp 16103-16118,

https://doi.org/10.1016/j.ceramint.2018.05.219

[5] Vaou, V. - Panias D. (2010): Thermal insulating foamy geopolymers from perlite. Minerals Engineering 23 (14) 1146-1151. https://doi.org/10.1016/j.mineng.2010.07.015

[6] Singh, S. - Aswath, M. U. - Ranganath, R. V. (2018): Effect of mechanical activation of red mud on the strength of geopolymer binder. Construction and Building Materials 177, pp. 91-101.

https://doi.org/10.1016/j.conbuildmat.2018.05.096

[7] Davidovits, J. (1994): Geopolymers: inorganic polymeric new materials. J. Mater. Educ. 16, pp. 91-139.

[8] Kumar, S. - Kumar, R., (2011): Mechanical activation of fly ash: Effect on reaction, structure and properties of resulting geopolymer. Ceramics International 37, pp. 533-541.

http://dx.doi.org/10.1016/j.ceramint.2010.09.038

[9] Molnár, Z. - Szabó, R. - Rácz, Á. - Lakatos, J. - Debreczeni, Á. - Mucsi, G. (2017): Optimization of activator solution and heat treatment of ground lignite type fly ash geopolymers. IOP CONFERENCE SERIES: MATERIALS SCIENCE AND ENGINEERING 175, pp. 1-8. https://doi:10.1088/1757-899X/175/1/012046

[10] Tchakouté, H. K. - Rüscher, C. H. - Kamseu, E. - Andreola, F. - Leonelli, C. (2017): Influence of the molar concentration of phosphoric acid solution on the properties of metakaolin-phosphate-based geopolymer cements. Applied Clay Science 147, pp. 184-194.

https://doi.org/10.1016/j.clay.2017.07.036

[11] Palomo, A. - Grutzeck, M. W. - Blanco, M. T. (1999): Alkali activated fly ashes: A cement for the future. Cement and Concrete Research. 29 pp. 1323-1329.

https://doi.org/10.1016/S0008-8846(98)00243-9
[12] Chindaprasirt, P. - Chareerat, T. - Sirivivatnanon, V. (2007): Workability and strength of coarse high calcium fly ash geopolymer. Cement and Concrete Composites, 29 (3); pp. 224-229.

https://doi.org/10.1016/j.cemconcomp.2006.11.002

[13] Wallah, S. E. - Rangan, B. V. (2006): Low-calcium fly ash-based geopolymer concrete: Long-term properties, Research report GC2, Faculty of Engineering, Curtin University of Technology,

[14] Živica, V. - Balkovic, S. - Drabik, M. (2011): Properties of metakaolin geopolymer hardened paste prepared by high-pressure compaction. Construction and Building Materials 25 (5), pp. 2206-2213. https://doi.org/10.1016/j.conbuildmat.2010.11.004

[15] Cheng, Y. - Hongqiang, M. - Hongyu, C. - Jiaxin, W. - Jing, S. - Zonghui, L. - Mingkai Y. (2018): Preparation and characterization of coal gangue geopolymers. Construction and Building Materials 187, pp. 318-326. https://doi.org/10.1016/j.conbuildmat.2018.07.220

[16] Mucsi, G. (2016):_Mechanical activation of power station fly ash by grinding - A review. Építőanyag 68:(2) pp. 56-61. http://dx.doi.org/10.14382/epitoanyag-jsbcm.2016.10

[17] Mádai F. - Kristály F. - Mucsi G. (2015): Microstructure, mineralogy and physical properties of ground fly ash based geopolymers. CeramicsSilikaty 59:(1) pp. 70-79.

[18] Kumar, R. - Kumar, S. - Mehrotra, S.P. (2007): Towards sustainable solutions for fly ash through mechanical activation. Resources, Conservation and Recycling 52, pp. 157-159. http://dx.doi.org/10.1016/j.resconrec.2007.06.007

[19] Panias, D. - Giannopoulou, I. P. - Perraki, T. (2007): Effect of synthesis parameters on the mechanical properties of fly ash-based geopolymers. Colloids and Surfaces A: Physicochemical Engineering Aspects 301 (1-3), pp.:246-254.

https://doi.org/10.1016/j.colsurfa.2006.12.064

[20] Rattanasak, U. - Chindaprasirt, P. (2009): Influence of $\mathrm{NaOH}$ solution on the synthesis of fly ash geopolymer. Minerals Engineering 22 (12), pp. 1073-1078.

https://doi.org/10.1016/j.mineng.2009.03.022

\section{Control of mechanical properties of lignite fly ash} based geopolymers by vibrating compression

The compression of geopolymer (and geopolymer concrete) can be performed by the usual methods used in the concrete technology, like compaction, tamping, and vibrating compression. This study focused on the vibrating compression of lignite fly ash based geopolymers. After the determination of the main properties of fly ash (like particle size distribution, specific surface area, moisture content, mineral and chemical composition) the effect of changing compression parameters (eccentricity, frequency and compression time) were investigated on the geopolymer properties. The uniaxial compressive strength and specimen density were measured at age of 7 days. Based on the results can be stated the changing of compression parameters resulted just a slight change on the specimen density (the values were between 1.4-1.45 g/cm3), but the compressive strength of geopolymer changed significantly (the values were between 7.9-12.8 MPa). Optimal compression parameters were the following: eccentricity of $10 \%$, motor frequency of $50 \mathrm{~Hz}$ and the compression time of 1 minute.

Keywords: lignite fly ash, geopolymer, vibrating compression, compressive strength, specimen density

\section{$\underline{\text { Ref.: }}$}

Szabó Roland: Lignit pernye alapú geopolimerek mechanikai tulajdonságainak szabályozása vibrációs tömöritéssel Építőanyag - Journal of Silicate Based and Composite Materials, Vol. 71, No. 2 (2019), 66-71. p. https://doi.org/10.14382/epitoanyag-jsbcm.2019.12 